\title{
Generation of Useful Hydrocarbons and Hydrogen during Photocatalytic Decomposition of Acetic Acid on CuO/Rutile Photocatalysts
}

\author{
Sylwia Mozia \\ Institute of Chemical and Environment Engineering, West Pomeranian University of Technology, ul. Pułaskiego 10, \\ 70-322 Szczecin, Poland \\ Correspondence should be addressed to Sylwia Mozia, sylwiam@ps.pl
}

Received 14 May 2009; Accepted 14 May 2009

Recommended by Mohamed Sabry Abdel-Mottaleb

\begin{abstract}
The presented studies have focused on a photocatalytic generation of useful hydrocarbons, mainly methane and ethane, from acetic acid under $\mathrm{N}_{2}$ atmosphere. CuO-loaded rutile, as well as unmodified rutile and anatase-phase $\mathrm{TiO}_{2}$ photocatalysts were applied in the experiments. The efficiency of the catalysts towards methane generation changed in the following order: $\mathrm{Cu}_{-} \mathrm{TiO}_{2}$ $(10 \% \mathrm{Cu})>$ crude $\mathrm{TiO}_{2} \approx \mathrm{Cu}-\mathrm{TiO}_{2}(20 \% \mathrm{Cu})>\mathrm{Cu}-\mathrm{TiO}_{2}(5 \% \mathrm{Cu})>$ rutile. The amount of $\mathrm{CH}_{4}$ produced in the presence of the catalyst containing $10 \mathrm{wt} \%$ of $\mathrm{Cu}$ was higher for ca. $33 \%$ than in case of pure rutile. The concentration of ethane was $14-16$ times lower than the amount of methane, regardless of the catalyst used. Low concentrations of hydrogen were also detected in the gaseous mixtures. After 5 hours of the process conducted with the catalyst containing $5-20 \mathrm{wt} \%$ of $\mathrm{Cu}$ the concentration of hydrogen amounted to $0.06-0.14$ vol.\%, respectively.
\end{abstract}

Copyright () 2009 Sylwia Mozia. This is an open access article distributed under the Creative Commons Attribution License, which permits unrestricted use, distribution, and reproduction in any medium, provided the original work is properly cited.

\section{Introduction}

Energy has progressively become a major global concern due to the depletion of natural resources and the global warming problem. Moreover, although the oil prices, compared to the prices in summer last year, have recently decreased due to the global recession, it is impossible to predict what oil prices will be next year. In view of this, the development of renewable energy sources is very important. Among numerous alternative energy sources, bioenergy, especially biogas, seems to be the most environmentally friendly and economically viable one. Moreover, except from being the source of energy, the biogas could be an effective solution to the wastes and wastewaters problem.

Biogas typically refers to a mixture of gases, mainly methane and carbon dioxide, produced by the anaerobic digestion or fermentation of organic matter under anaerobic conditions. Other compounds present in the biogas could be $\mathrm{N}_{2}, \mathrm{H}_{2}, \mathrm{H}_{2} \mathrm{~S}, \mathrm{O}_{2}, \mathrm{CO}, \mathrm{H}_{2} \mathrm{O}$, and $\mathrm{NH}_{3}$. The composition of biogas varies depending on the origin of wastes used in the anaerobic digestion process as well as the process conditions.
The traditional production of biogas based on anaerobic digestion technology requires the presence of particular kinds of bacteria. The methanogenic bacteria are highly sensitive to the $\mathrm{O}_{2}$ concentration in the system and their activities depend on the concentrations of fatty and acetic acids, and the $\mathrm{pH}$ value [1]. In addition, bacteria are not able to treat substances which are biorecalcitrant (e.g., herbicides) or bactericide. This reduces the number of possible sources for biogas generation to those which do not contain substances dangerous to the bacteria [2].

In view of this, it seems to be beneficial to find another solution for conversion of wastewaters into useful energy (biogas). In our opinion, such a solution could be development of biogas production via photocatalytic decomposition of organic compounds. Photocatalysis is not specific (or almost not) for particular substrates what means that could be applied for any type of wastewaters, regardless of its toxicity. Therefore, different biogas sources could be utilized for photocatalytic generation of biogas, or "photobiogas".

Most of the already published papers [3-11] on photocatalytic production of methane concern reduction of $\mathrm{CO}_{2}$ 
under UV light in the presence of pure or modified $\mathrm{TiO}_{2}$. The reactions were carried out either in liquid or in gaseous phase. The efficient photoreduction of carbon dioxide in aqueous medium was found to be difficult since the solubility of carbon dioxide is rather low (ca. $0.03 \mathrm{~mol} / \mathrm{dm}^{3}$ at ambient conditions) [11]. Therefore, attempts to conduct the process in gaseous phase were made [12-14]. Generation of methane from $\mathrm{CO}_{2}$ is often proposed as a method of solving the global warming problem. Another very important environmental problem is treatment of wastewaters. As was mentioned earlier, the photocatalytic production of methane from sewage is supposed to be helpful in solving this problem.

Literature data concerning photocatalytic generation of methane from organic compounds in liquid phase are very limited. All of them concern production of $\mathrm{CH}_{4}$ from aliphatic acids [15-18] and alcohols [19]. In 1970's Kraeutler and Bard [15-17] published a series of papers concerning photocatalytic decarboxylation of acetic acid in the presence of $\mathrm{Pt} / \mathrm{TiO}_{2}$ catalyst. The main products of the reaction were methane and carbon dioxide. Similarly, Sakata et al. [18] observed formation of methane and ethane during photodecomposition of acetic and propionic acids in the presence of $\mathrm{TiO}_{2}$ and $\mathrm{Pt} / \mathrm{TiO}_{2}$.

One of the crucial points in the photocatalytic generation of methane from organic compounds is development of an effective photocatalyst. Most of literature data on the photocatalytic production of methane in aqueous phase show application of $\mathrm{TiO}_{2}$ or $\mathrm{Pt} / \mathrm{TiO}_{2}$ photocatalysts [1518]. In the presented studies we have focused on preparation of CuO-modified rutile photocatalysts and their application in photocatalytic generation of methane in $\mathrm{N}_{2}$ atmosphere. $\mathrm{CuO}$ was selected on a basis of literature data [3, 20-23]. For example, Slamet et al. [3] found that $\mathrm{CuO}$ was very effective modifying agent in photoreduction of $\mathrm{CO}_{2}$. The authors investigated the effect of modification of $\mathrm{TiO}_{2}$ with $\mathrm{CuO}, \mathrm{Cu}_{2} \mathrm{O}$ and $\mathrm{Cu}$ and found that $\mathrm{CuO}$ was the most active modifier compared to the other species. Sreethawong and Yoshikawa [23] reported that $\mathrm{CuO} / \mathrm{TiO}_{2}$ photocatalysts exhibited significant activity in photocatalytic hydrogen evolution. Taking into consideration these data, $\mathrm{CuO}$ was selected as a modifying agent in the presented experiments. Acetic acid was used as a source of the "photobiogas". Application of acetic acid as a model compound seems to be reasonable since amongst the final by-products of photocatalytic degradation of most organic compounds in water different aliphatic acids, including $\mathrm{CH}_{3} \mathrm{COOH}$, are present.

\section{Experimental}

The catalysts used in this study were prepared from crude $\mathrm{TiO}_{2}$ obtained directly from the Chemical Factory "Police" (Poland). The crude $\mathrm{TiO}_{2}$ was modified with $\mathrm{CuCl}_{2} \cdot 2 \mathrm{H}_{2} \mathrm{O}$ as follows. A defined amount of $\mathrm{TiO}_{2}$ was introduced into a beaker containing aqueous solution of modifying agent and stirred for 22 hours. After that water was evaporated and the samples were dried at $105^{\circ} \mathrm{C}$ for 24 hours in an oven. Such prepared samples were calcinated at $700^{\circ} \mathrm{C}$ in Ar atmosphere $\left(5 \mathrm{dm}^{3} / \mathrm{h}\right)$ for 1 hour. The amount of $\mathrm{Cu}$ introduced to the samples was 5,10 or $20 \mathrm{wt} \%$. In order to compare the results, a sample containing rutile phase without $\mathrm{CuO}$ was prepared by annealing of crude $\mathrm{TiO}_{2}$ at $800^{\circ} \mathrm{C}$ for 1 hour in air. At the temperature of $700^{\circ} \mathrm{C}$, which was applied for preparation of $\mathrm{CuO} /$ rutile catalysts, the anatase phase, not rutile, was obtained. Therefore, the temperature of $800^{\circ} \mathrm{C}$ was selected for preparation of pure rutile without $\mathrm{CuO}$.

$\mathrm{X}$-ray diffraction (XRD) analyses were performed on a powder diffractometer Philips X'Pert PRO $\left(\mathrm{CuK}_{\alpha}, 35 \mathrm{kV}\right.$, $30 \mathrm{~mA}$ ). UV-VIS/DR spectra were recorded using Jasco V 530 spectrometer (Japan) equipped with the integrating sphere accessory for diffuse reflectance spectra. $\mathrm{BaSO}_{4}$ was used as a reference.

The photocatalytic reaction was conducted in a cylindrical glass reactor containing $0.35 \mathrm{dm}^{3}$ of $\mathrm{CH}_{3} \mathrm{COOH}$ $\left(1 \mathrm{~mol} / \mathrm{dm}^{3}\right)$ and $0.35 \mathrm{~g}$ of a catalyst. At the beginning of the experiment $\mathrm{N}_{2}$ was bubbled through the reactor for at least 3 hours to ensure that the dissolved oxygen was eliminated. Then, the UV lamp $\left(\lambda_{\max }=365 \mathrm{~nm}\right)$, positioned in the center of the reactor, was turned on to start the photoreaction. Gaseous products were analyzed using GC SRI 8610C equipped with TCD and HID detectors, and Shincarbon (carbon molecular sieve; $4 \mathrm{~m}, 1 \mathrm{~mm}, 10$ $120 \mathrm{mesh}$ ) and molecular sieve 5A (2 m, 2 mm, 80-100 mesh) columns. Helium was used as a carrier gas.

\section{Results and Discussion}

Figure 1 presents XRD patterns of crude $\mathrm{TiO}_{2}$ and photocatalysts modified with $\mathrm{CuO}$. It can be observed that crude $\mathrm{TiO}_{2}$ contained almost pure (97\%) anatase phase. The diffraction lines were weak and broad suggesting poor crystallinity of the sample. The crystallite size of anatase in the crude $\mathrm{TiO}_{2}$ was $9 \mathrm{~nm}$. The catalysts containing 5 and $10 \mathrm{wt} \% \mathrm{Cu}$ were composed of rutile and $\mathrm{CuO}$ only. In case of the sample containing $20 \mathrm{wt} \%$ of $\mathrm{Cu}$, except from rutile and $\mathrm{CuO}$ phases, $\mathrm{CuCl}$ was also identified. The presence of $\mathrm{CuCl}$ suggests that the amount of $\mathrm{CuCl}_{2}$ used was too high and the transformation of $\mathrm{CuCl}_{2}$ to $\mathrm{CuO}$ was not complete under the conditions applied. Some amount of copper (II) was reduced to copper (I) forming $\mathrm{CuCl}$. The sample prepared by calcination of crude $\mathrm{TiO}_{2}$ at $800^{\circ} \mathrm{C}$ and denoted later as rutile consisted of $97 \%$ of rutile and $3 \%$ of anatase [24]. As was mentioned earlier (see Section 2), the temperature of $800^{\circ} \mathrm{C}$ was selected because application of calcination temperature of $700^{\circ} \mathrm{C}$ resulted not in rutile, but anatase phase. These data clearly show that the presence of $\mathrm{CuO}$ strongly affects the temperature of phase transformation from anatase to rutile. Such a phenomenon was already reported in literature [25]. Francisco and Mastelaro [25] explained it by catalyzing properties of copper oxide. $\mathrm{CuO}$ probably catalyzes the mass transport to the nucleation region of rutile phase, promoting rutile nuclei growth, thus favoring the phase transition. $\mathrm{CuO}$ is responsible for a higher number of defects inside the anatase phase, in such a way that formation and growth of a higher number of rutile nuclei into $\mathrm{TiO}_{2}$ anatase take place faster. The mechanism responsible for such a modification is an excess of oxygen vacancies that accelerates the transition and the crystallite growth [25]. 


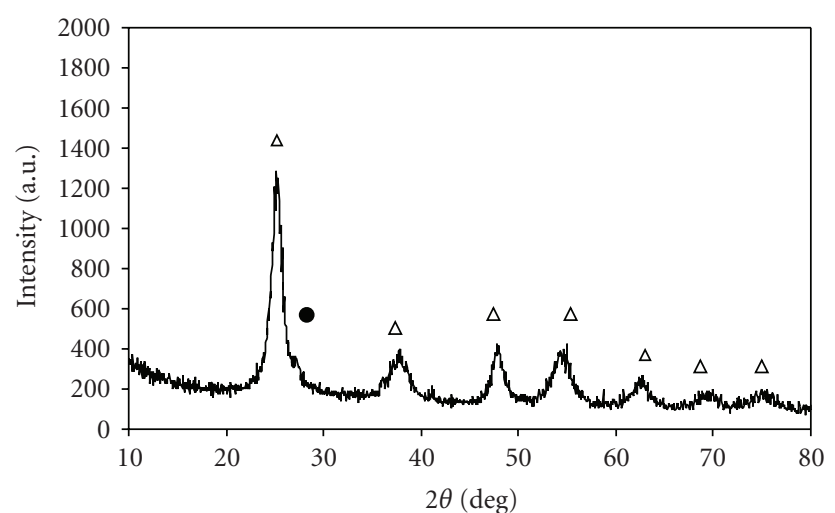

(a)

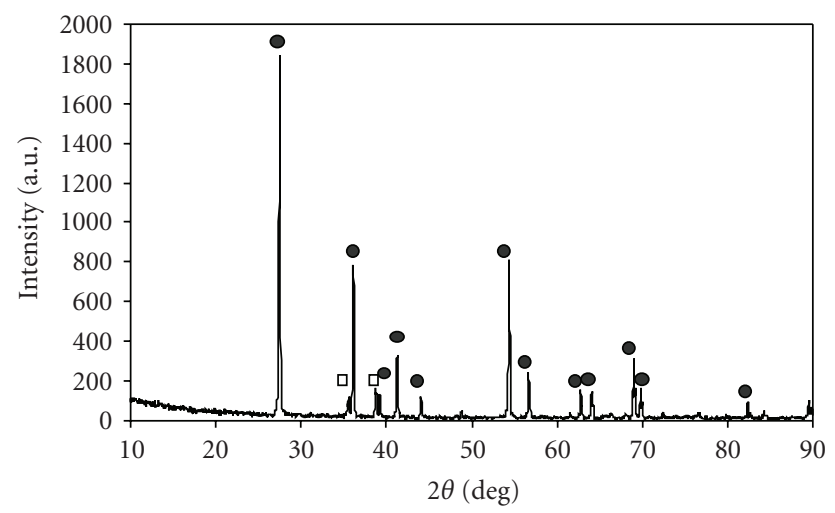

(b)

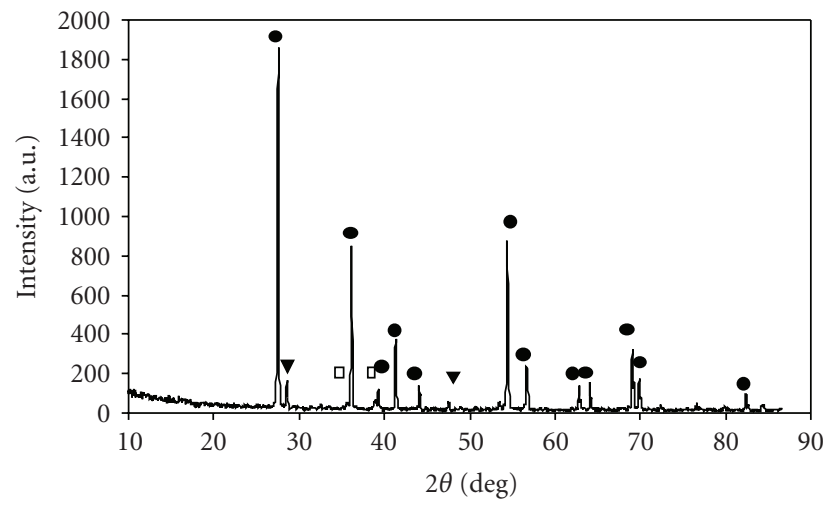

(c)

Figure 1: XRD patterns of crude $\mathrm{TiO}_{2}$ and $\mathrm{Cu}$-modified photocatalysts: (a) crude $\mathrm{TiO}_{2}$; (b) photocatalyst containing $10 \mathrm{wt} \% \mathrm{Cu}$; (c) photocatalyst containing $20 \mathrm{wt} \% \mathrm{Cu}$. •-rutile; $\Delta$-anatase; $\square$-CuO; $\boldsymbol{\nabla}-\mathrm{CuCl}$.

The crystallite size of rutile calculated on a basis of the Scherrer equation was similar for pure rutile and $\mathrm{CuO} /$ rutile catalysts and ranged from 300 to $320 \mathrm{~nm}$, respectively. However, since $100 \mathrm{~nm}$ is generally considered the upper limit for XRD crystal size measurements, these data cannot be interpreted as accurate dimensions of the rutile crystals. The only conclusion could be that crystallite sizes of rutile in all of the samples (i.e., pure rutile and $\mathrm{CuO} / \mathrm{TiO}_{2}$ ) were similar. This might lead to the conclusion that the crystallite size of rutile, being almost the same for all the samples,

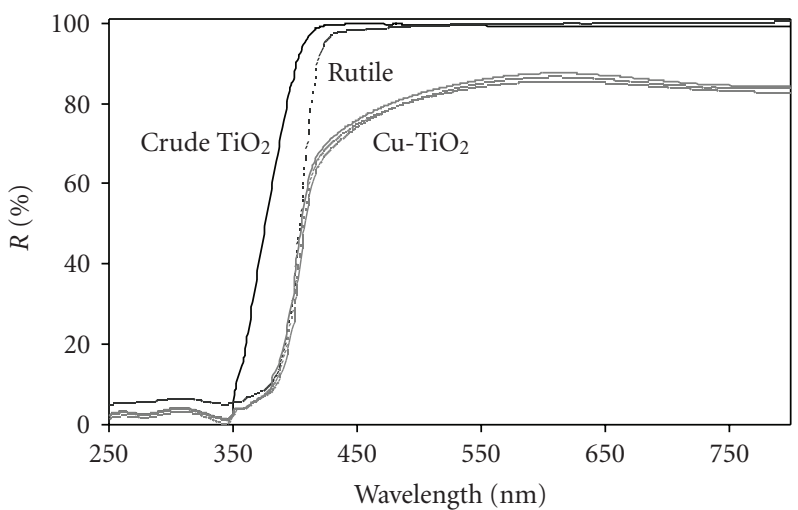

FIgURE 2: UV/Vis-DR spectra of crude $\mathrm{TiO}_{2}$, rutile and $\mathrm{Cu}$-rutile photocatalysts.

should not affect the photocatalytic behavior of the $\mathrm{CuO}$ modified rutile.

Figure 2 shows UV-Vis/DR spectra of crude $\mathrm{TiO}_{2}$, rutile and $\mathrm{Cu}$-modified catalysts. It can be observed that all the spectra of $\mathrm{CuO}$-rutile photocatalysts exhibit a similar course and are red shifted for over $30 \mathrm{~nm}$ relative to crude $\mathrm{TiO}_{2}$, what indicates a decrease of the band gap energy. This decrease was associated with phase transformation from anatase to rutile. A similar red shift relative to crude $\mathrm{TiO}_{2}$ can be observed in case of pure rutile. To determine the band gap energy $\left(E_{g}\right)$ of the samples, the Kubelka-Munk method was used. The $E_{g}$ values were calculated from the $(F(R) h v)^{1 / 2}$ versus $h v$ plots, where $F(R)=(1-R) / 2 R$ [26]. The absorption edge for crude $\mathrm{TiO}_{2}$ was found to be $378 \mathrm{~nm}$, which value corresponded to the band gap energy of $E_{g}=3.28 \mathrm{eV}$. The absorption edges determined for pure rutile and $\mathrm{CuO}$-rutile samples were 412 and $414 \mathrm{~nm}$, what corresponded to $E_{g}$ of 3.01 and $2.99 \mathrm{eV}$, respectively. From Figure 2 it can be also found that $\mathrm{CuO}$-rutile catalysts absorbed more visible light than pure $\mathrm{TiO}_{2}$. The increased absorption in the Vis region was due to grey color of the $\mathrm{CuO}$-modified photocatalysts.

The $\mathrm{TiO}_{2}$ and $\mathrm{Cu}-\mathrm{TiO}_{2}$ photocatalysts were applied for the photocatalytic decomposition of acetic acid under $\mathrm{N}_{2}$ atmosphere. The reaction was conducted for 5 hours. Figure 3 presents changes of concentration of methane in gaseous mixtures versus time of irradiation.

For the initial 2 hours of the process, no significant difference in the amount of methane generated on different catalysts was observed. The concentration of $\mathrm{CH}_{4}$ was in the range of $0.24-0.28 \mathrm{vol} \%$ what corresponded to $0.12-$ $0.14 \mathrm{mmolCH}_{4} / \mathrm{molCH}_{3} \mathrm{COOH}$. However, with increasing time of irradiation the differences between the amounts of methane formed with application of different catalysts were becoming more significant. After 5 hours of irradiation the pure rutile was found to be the least efficient catalyst. The amount of methane formed in the presence of rutile was ca. 0.6 vol. $\%$, what corresponded to $0.29 \mathrm{mmolCH}_{4} / \mathrm{molCH}_{3} \mathrm{COOH}$. The highest amount of methane was generated in case of the catalyst containing $10 \mathrm{wt} \%$ of $\mathrm{Cu}$. After 5 hours of irradiation the 


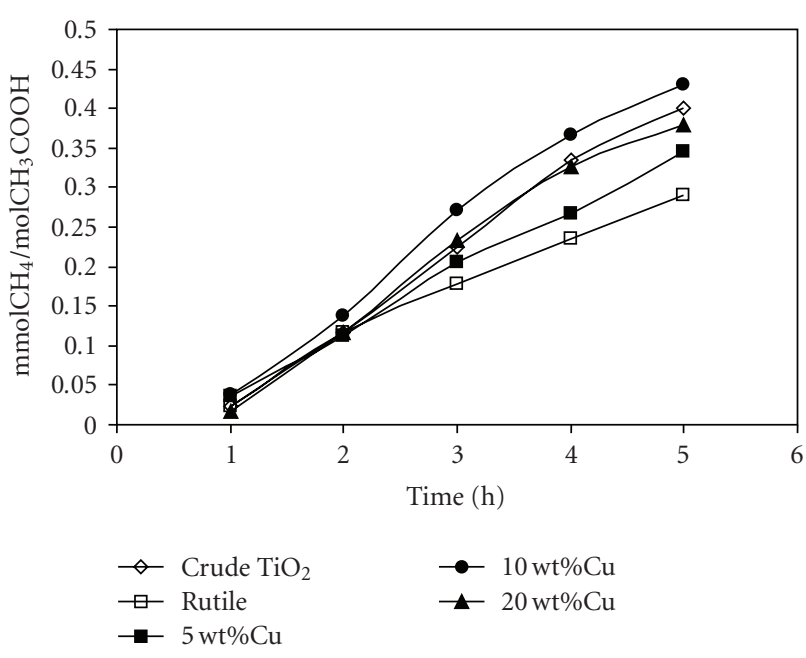

FIGURE 3: Photocatalytic generation of methane on different photocatalysts.

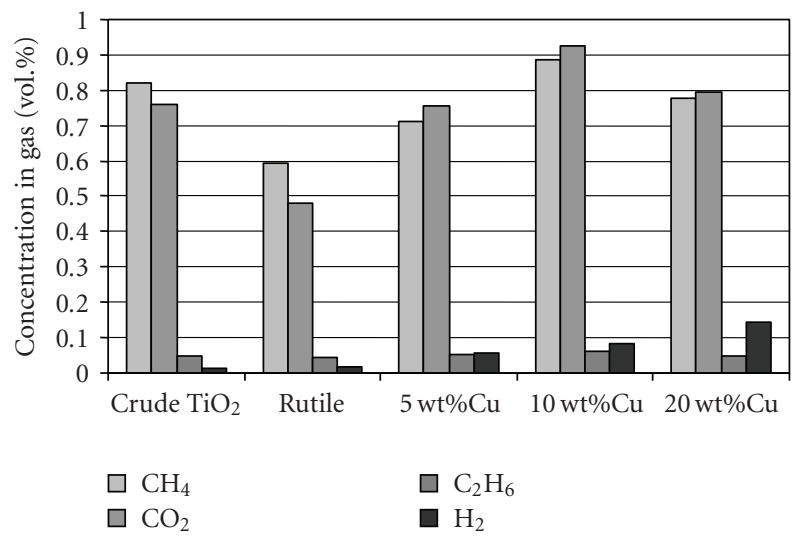

Figure 4: A comparison of the amount of products obtained after 5 hours of reaction conducted with different photocatalysts.

concentration of $\mathrm{CH}_{4}$ in gaseous mixture was 0.88 vol.\% $\left(0.43 \mathrm{mmolCH}_{4} / \mathrm{molCH}_{3} \mathrm{COOH}\right)$. On the basis of the results presented in Figure 3, the efficiency of the catalysts toward methane generation can be put in the following order: $\mathrm{Cu}$ $\mathrm{TiO}_{2}(10 \% \mathrm{Cu})>$ crude $\mathrm{TiO}_{2} \approx \mathrm{Cu}-\mathrm{TiO}_{2}(20 \% \mathrm{Cu})>\mathrm{Cu}-$ $\mathrm{TiO}_{2}(5 \% \mathrm{Cu})>$ rutile. It should be noticed here that all the rutile catalysts containing $\mathrm{CuO}$ were more active than pure rutile. The amount of methane generated on $\mathrm{Cu}$-rutile photocatalyst was higher than that obtained in case of pure rutile for ca. 16,33 and $24 \%$, for catalysts containing 5$20 \mathrm{wt} \%$ of $\mathrm{Cu}$, respectively.

Taking into consideration the above results, the catalyst containing $10 \mathrm{wt} \%$ of $\mathrm{Cu}$ was further applied in a long term process. Irradiation was conducted for 28 hours. It was found that the amount of methane generated was continuously increasing with increasing time of irradiation. After 5 hours of the process the concentration of methane in gas amounted to 0.88 vol. $\%$, whereas after 28 hours the amount of methane increased up to $3.66 \mathrm{vol} . \%$.

Another gaseous products which were identified in the reaction mixture were carbon dioxide and ethane. Figure 4 shows a comparison of the amount of these compounds generated after 5 hours of irradiation. From the obtained data it was found that the main products of acetic acid decomposition were methane and carbon dioxide. The lowest concentrations of $\mathrm{CH}_{4}$ and $\mathrm{CO}_{2}$ in the gaseous mixture were obtained in case of pure rutile, whereas the highest-in case of rutile containing $10 \mathrm{wt} \%$ of $\mathrm{Cu}$. The ratio of $\mathrm{CH}_{4} / \mathrm{CO}_{2}$ formation was found to be in the range of 0.94-0.98 in case of CuO-modified $\mathrm{TiO}_{2}$, ca. 1.1 in case of crude $\mathrm{TiO}_{2}$ and about 1.2 for rutile. These data clearly show that for pure $\mathrm{TiO}_{2}$ the amount of methane was higher than the amount of $\mathrm{CO}_{2}$. On the contrary in case of the $\mathrm{CuO}$ rutile catalysts the concentration of $\mathrm{CO}_{2}$ was higher than concentration of $\mathrm{CH}_{4}$. In Figure 4 it can be also observed that the amount of ethane was significantly lower than the amount of methane and carbon dioxide, regardless of the catalyst used. The lowest concentration of ethane after 5 hours of irradiation was observed for rutile (0.043 vol.\%) and the highest for $\mathrm{CuO} /$ rutile catalyst containing $10 \mathrm{wt} \%$ of $\mathrm{Cu}$ (0.062 vol.\%). The ratio of $\mathrm{CH}_{4} / \mathrm{C}_{2} \mathrm{H}_{6}$ was found to be about 14-16.

Taking into consideration that the main gaseous products identified were methane and carbon dioxide and that the $\mathrm{CH}_{4} / \mathrm{CO}_{2}$ ratio was about 1 , it might be concluded that the photodecomposition of acetic acid followed the so-called "photo-Kolbe" reaction pathway [15-17]:

$$
\mathrm{CH}_{3} \mathrm{COOH} \longrightarrow \mathrm{CH}_{4}+\mathrm{CO}_{2} \text {. }
$$

Reaction (1) represents the photocatalytic decarboxylation of acetic acid under anaerobic conditions. The reaction is initiated by photogenerated holes and can be also written as follows [27]:

$$
\begin{gathered}
\mathrm{CH}_{3} \mathrm{COOH}+h^{+} \longrightarrow \mathrm{CH}_{3}^{\bullet}+\mathrm{CO}_{2}+\mathrm{H}^{+}, \\
\mathrm{H}^{+}+\mathrm{e}^{-} \longrightarrow \mathrm{H}^{\bullet}, \\
\mathrm{CH}_{3}{ }^{\bullet}+\mathrm{H}^{\bullet} \longrightarrow \mathrm{CH}_{4} .
\end{gathered}
$$

The reaction of the formation of ethane from acetic acid can be presented as follows [18]:

$$
2 \mathrm{CH}_{3} \mathrm{COOH} \longrightarrow \mathrm{C}_{2} \mathrm{H}_{6}+2 \mathrm{CO}_{2}+\mathrm{H}_{2} \text {, }
$$

or, taking into consideration the recombination of methyl radicals [27]:

$$
\mathrm{CH}_{3} \cdot \mathrm{CH}_{3}^{\bullet} \longrightarrow \mathrm{C}_{2} \mathrm{H}_{6} \text {. }
$$

Reactions (5) and (6) in the discussed system are minor ones, what can be concluded on a basis of the obtained data (Figure 4) showing that the amount of ethane was significantly lower than that of methane.

From Figure 4 it can be also found that amongst the gaseous products of the reaction hydrogen was present. Changes of $\mathrm{H}_{2}$ concentration in time of the experiment are presented in Figure 5. It can be observed that in case of crude $\mathrm{TiO}_{2}$ and pure rutile the amount of hydrogen was significantly lower than of the $\mathrm{Cu}$-modified photocatalysts. In case of the catalysts containing $\mathrm{CuO}$ the $\mathrm{H}_{2}$ concentration 


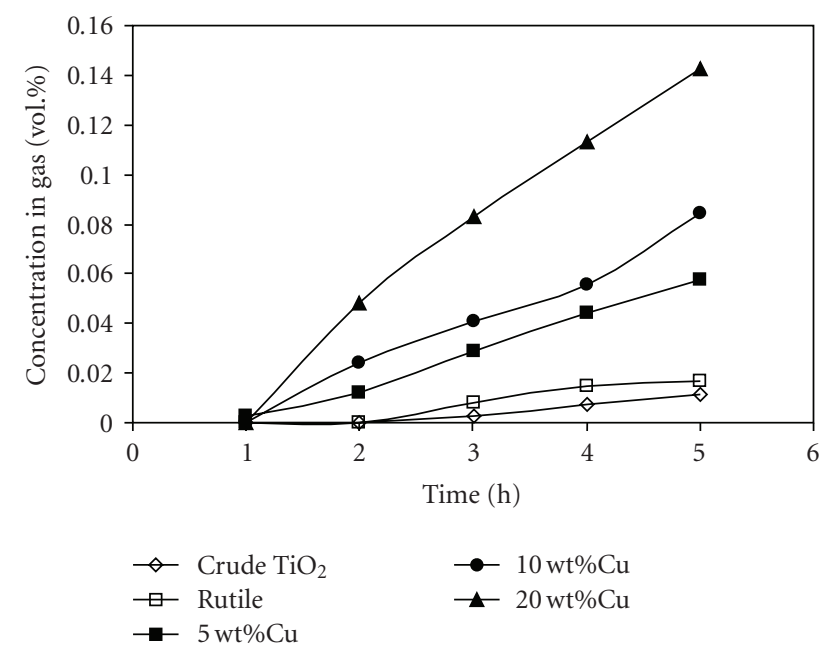

Figure 5: Photocatalytic generation of hydrogen on different photocatalysts.

was increasing with increasing $\mathrm{Cu}$ loading. After 5 hours of irradiation about $0.06-0.14$ vol.\% of $\mathrm{H}_{2}$ was obtained for photocatalysts containing $5-20 \mathrm{wt} \%$ of $\mathrm{Cu}$, respectively.

The photocatalytic evolution of hydrogen in the presence of sacrificial agents has been already described in the literature [18, 20-22, 26-34]. In general, when the reducing agent, or hole scavenger, such as alcohol [20, 23, 26-29], organic acid $[18,30,31]$ or sulfide ion $[32,33]$, is present in the solution, the photogenerated holes react with the reducing agent. As a result the photocatalyst is enriched with electrons and $\mathrm{H}_{2}$ evolution reaction is enhanced [34]:

$$
2 \mathrm{H}^{+}+2 \mathrm{e}^{-} \longrightarrow \mathrm{H}_{2}
$$

According to Kudo and Miseki [34] the hydrogen evolution in the presence of sacrificial agent does not mean the "water splitting". Water splitting means to split water into $\mathrm{H}_{2}$ and $\mathrm{O}_{2}$ in a stoichiometric amount in the absence of sacrificial reagents [34].

The photocatalytic hydrogen evolution can be enhanced by modification of $\mathrm{TiO}_{2}$. Literature data [20-23] show that $\mathrm{CuO} / \mathrm{TiO}_{2}$ photocatalysts are very effective in $\mathrm{H}_{2}$ generation. The $\mathrm{TiO}_{2}$ acts as the primary catalyst and $\mathrm{CuO}$ acts as a cocatalyst, helping charge separation [20]. After absorption of a photon $(h v)$ with sufficient energy, that is, equal or higher than the band gap energy $\left(E_{g}\right)$ of $\mathrm{TiO}_{2}$, the electrons and holes are generated. The hole scavenger consumes holes in the valence band rapidly leaving electrons in the conduction band of $\mathrm{TiO}_{2}$. The conduction band (CB) of $\mathrm{CuO}$ is positioned below the $\mathrm{CB}$ of $\mathrm{TiO}_{2}$ which allows transfer of electrons from the $\mathrm{CB}$ of $\mathrm{TiO}_{2}$ to the $\mathrm{CB}$ of $\mathrm{CuO}$. These results in a more negative $\mathrm{CB}$ potential of $\mathrm{CuO}$ and, as a result, enhanced hydrogen evolution. The yield of $\mathrm{H}_{2}$ evolution greatly relies on the competition between the trapping of the excited electrons by cocatalyst active sites followed by reduction reaction and the electron-hole recombination [23]. As was mentioned earlier, the amount of hydrogen in case of the Cu-modified photocatalysts was significantly higher than in case of pure $\mathrm{TiO}_{2}$. This might lead to a conclusion that the limited hydrogen evolution in case of crude $\mathrm{TiO}_{2}$ and rutile resulted from rapid recombination of holes and electrons, since the separation of electron-hole pairs in case of pure $\mathrm{TiO}_{2}$ is not as efficient as in the presence of $\mathrm{CuO}$.

The source of hydrogen in case of the photocatalytic reactions conducted in the presence of sacrificial agents is still under debate. Bandara et al. [20] have argued that $\mathrm{H}_{2}$ is produced from water. They have drawn such a conclusion on a basis of the experiment performed with application of absolute methanol. During this process no $\mathrm{H}_{2}$ evolution was observed. On the other hand, Sakata et al. [18] proposed that $\mathrm{H}_{2}$ formation is due to photocatalytic decomposition of acetic acid:

$$
\begin{gathered}
\mathrm{CH}_{3} \mathrm{COOH}+h^{+} \longrightarrow{ }^{\bullet} \mathrm{CH}_{3}+\mathrm{CO}_{2}+\mathrm{H}^{+}, \\
{ }^{\bullet} \mathrm{CH}_{3}+{ }^{\bullet} \mathrm{OH} \longrightarrow \mathrm{CH}_{3} \mathrm{OH}
\end{gathered}
$$

or

$$
\mathrm{CH}_{3} \mathrm{COOH}+2^{\bullet} \mathrm{OH} \longrightarrow \mathrm{HOCH}_{2} \mathrm{COOH}+\mathrm{H}_{2} \mathrm{O} \text {. }
$$

In the next step, $\mathrm{CH}_{3} \mathrm{OH}$ and $\mathrm{HOCH}_{2} \mathrm{COOH}$ are decomposed into carbon dioxide and hydrogen:

$$
\begin{gathered}
\mathrm{CH}_{3} \mathrm{OH}+\mathrm{H}_{2} \mathrm{O} \longrightarrow \mathrm{CO}_{2}+3 \mathrm{H}_{2}, \\
\mathrm{HOCH}_{2} \mathrm{COOH}+\mathrm{H}_{2} \mathrm{O} \longrightarrow 2 \mathrm{CO}_{2}+3 \mathrm{H}_{2} .
\end{gathered}
$$

The overall reaction summarizing (8)-(12) can be written as follows:

$$
\mathrm{CH}_{3} \mathrm{COOH}+2 \mathrm{H}_{2} \mathrm{O} \longrightarrow 2 \mathrm{CO}_{2}+4 \mathrm{H}_{2} \text {. }
$$

The photocatalytic decomposition of methanol was also presented as follows [29]:

$$
\begin{gathered}
\mathrm{CH}_{3} \mathrm{OH} \longrightarrow \mathrm{HCHO}+3 \mathrm{H}_{2}, \\
\mathrm{HCHO}+\mathrm{H}_{2} \mathrm{O} \longrightarrow \mathrm{HCO}_{2} \mathrm{H}+\mathrm{H}_{2}, \\
\mathrm{HCO}_{2} \mathrm{H} \longrightarrow \mathrm{CO}_{2}+\mathrm{H}_{2} .
\end{gathered}
$$

From the mechanism proposed by Sakata et al. [18] it can be found that $\mathrm{H}_{2}$ is produced from methanol and glycolic acid, which are formed from acetic acid ( (9) and (10)). These two reactions are possible when hydroxyl radicals are present in the solution. However, in the low $\mathrm{pH}$ region the amount of $\mathrm{OH}^{\bullet}$ radicals formed is not high due to low concentration of $\mathrm{OH}^{-}$. Therefore, the amount of methanol and glycolic acid which might be produced in the reactions (9) and (10) should be rather low. This leads to a conclusion that in the low $\mathrm{pH}$ region the reaction (13) is of minor importance [18]. In view of this, it is more probable that the hydrogen ions come mainly from decomposition of acetic acid presented by (8), rather than from decomposition of methanol or glycolic acid (reactions (11) and (12)). Water could be also involved in $\mathrm{H}_{2}$ generation through the reaction (7), however, according to Jang et al. [33] its effect should be insignificant due to the low concentration of protons in neutral water. Summing up, the photocatalytic evolution of $\mathrm{H}_{2}$ in the 
presence of acetic acid as a sacrificial agent was probably mainly due to reduction of protons $\left(\mathrm{H}^{+}\right)$generated during decomposition of $\mathrm{CH}_{3} \mathrm{COOH}(8)$. Moreover, it can be also supposed that some amount of hydrogen was generated from by-products of acetic acid decomposition, such as methanol and glycolic acid, as well as from water molecules. However, the $\mathrm{H}_{2}$ evolution during the latter two processes compared to the overall hydrogen evolution is supposed to be of minor importance.

An evidence for the supposition that the source of hydrogen is acetic acid, not water, might be also the ratio of methane to carbon dioxide concentrations (Figure 4). As was mentioned earlier, in case of crude $\mathrm{TiO}_{2}$ and rutile the amount of methane was higher than the amount of $\mathrm{CO}_{2}$, whereas for $\mathrm{CuO}-\mathrm{TiO}_{2}$ catalysts the concentration of $\mathrm{CH}_{4}$ was lower than $\mathrm{CO}_{2}$. This might suggest that in case of these two types of photocatalysts some other reactions, despite of those described by (1)-(6) took place. One explanation might be generation of hydrogen from acetic acid. Assuming that both, methane and at least part of the hydrogen were produced from acetic acid, the amounts of these compounds should depend on the efficiency of the reactions of their formation. Thus, the higher amount of $\mathrm{H}_{2}$, the lower amount of $\mathrm{CH}_{4}$ should be generated, since $\mathrm{H}^{+}$would take part in reaction (7) instead of (1)-(4). In case of pure $\mathrm{TiO}_{2}$ the amount of $\mathrm{H}_{2}$ was very low and therefore the $\mathrm{CH}_{4} / \mathrm{CO}_{2}$ ratio was above 1 . For the $\mathrm{CuO}-\mathrm{TiO}_{2}$ catalysts higher amount of hydrogen was generated, what might be supposed to be a reason of a decrease of $\mathrm{CH}_{4}$ concentration. Moreover, the effect of $\mathrm{C}_{2} \mathrm{H}_{6}$ and possibly higher hydrocarbons formation on methane concentration in the reaction mixture should be also taken into consideration. However, taking into account that the amount of $\mathrm{C}_{2} \mathrm{H}_{6}$ was comparable for all the catalysts used $\left(0.02-0.03 \mathrm{mmolC}_{2} \mathrm{H}_{6} / \mathrm{molCH}_{3} \mathrm{COOH}\right.$ after 5 hours of irradiation) the effect of ethane generation on $\mathrm{CH}_{4} / \mathrm{CO}_{2}$ ratio seems to be of lower importance. Besides, it might be also supposed that a certain amount of carbon dioxide was reduced to $\mathrm{CH}_{4}$, what might be concluded from the fact that the concentration of $\mathrm{CO}_{2}$ in case of crude $\mathrm{TiO}_{2}$ and rutile was lower than that of methane. Literature data $[3,8,9,35]$ show that the reduction of carbon dioxide in the presence of various types of modified $\mathrm{TiO}_{2}$ is possible. However, in order to state unequivocally what affects the $\mathrm{CH}_{4} / \mathrm{CO}_{2}$ ratio in the presence of pure $\mathrm{TiO}_{2}$ and $\mathrm{CuO} / \mathrm{TiO}_{2}$ catalysts, further investigations are necessary.

Summing up, from the presented data (Figures 3 and 4) it can be clearly seen that the most active photocatalyst towards hydrocarbons (i.e., methane and ethane) generation was $\mathrm{Cu}-\mathrm{TiO}_{2}$ containing $10 \mathrm{wt} \% \mathrm{Cu}$. Since the crystallite size of rutile in all of the $\mathrm{Cu}$-modified photocatalysts as well as in pure rutile could be assumed to be comparable, it might be supposed that the highest photoactivity of $\mathrm{Cu}$ $\mathrm{TiO}_{2}(10 \% \mathrm{Cu})$ was associated with the amount of $\mathrm{CuO}$ present in this sample. The photocatalytic activity of rutiletype samples increased as follows: pure rutile $<\mathrm{Cu}-\mathrm{TiO}_{2}$ $(5 \% \mathrm{Cu})<\mathrm{Cu}-\mathrm{TiO}_{2}(10 \% \mathrm{Cu})$, what suggests that $5 \mathrm{wt} \%$ of $\mathrm{Cu}$ was below the optimum value. Taking into consideration that in case of the $\mathrm{Cu}-\mathrm{TiO}_{2}$ containing $20 \mathrm{wt} \% \mathrm{Cu}$ the yield of $\mathrm{CH}_{4}$ formation decreased, one might draw a conclusion that this sample was overloaded with $\mathrm{CuO}$. This overloading might have led to a "shading effect" of $\mathrm{CuO}$ [3], which means that particles of copper oxide covered most of active sites of titania. As a result, the $\mathrm{TiO}_{2}$ surface accessible to acetic acid molecules decreased and the yield of the "photoKolbe" reaction also decreased. However, the efficiency of photocatalysts toward hydrogen evolution (Figures 4 and 5) was as follows: $\mathrm{Cu}-\mathrm{TiO}_{2}(20 \% \mathrm{Cu})>\mathrm{Cu}-\mathrm{TiO}_{2}(10 \% \mathrm{Cu})>$ $\mathrm{Cu}-\mathrm{TiO}_{2}(5 \% \mathrm{Cu})>$ rutile $\approx$ crude $\mathrm{TiO}_{2}$. These results show that the catalyst which was the most effective in methane production (i.e., containing $10 \mathrm{wt} \% \mathrm{Cu}$ ) was the second one in case of hydrogen generation. Therefore, the explanation about "shading effect" of $\mathrm{CuO}$ in case of the catalyst containing $20 \mathrm{wt} \% \mathrm{Cu}$ seems to be unsatisfactory. In view of these, more probable explanation is that at higher $\mathrm{CuO}$ content, higher amount of acetic acid molecules took place in the reaction of $\mathrm{H}_{2}$ formation rather than $\mathrm{CH}_{4}$ generation. Therefore, since the amount of substrate, that is, $\mathrm{CH}_{3} \mathrm{COOH}$, was always the same, the increased production of hydrogen should lead to a decreased production of methane, what was observed in the discussed experiments.

\section{Conclusions}

It was found that it is possible to generate useful hydrocarbons, such as $\mathrm{CH}_{4}$ and $\mathrm{C}_{2} \mathrm{H}_{6}$, from acetic acid in the presence of $\mathrm{Cu}$-modified rutile under UV irradiation. The efficiency of the catalysts toward methane generation changed in the following order: $\mathrm{Cu}-\mathrm{TiO}_{2}(10 \% \mathrm{Cu})>$ crude $\mathrm{TiO}_{2} \approx \mathrm{Cu}-\mathrm{TiO}_{2}$ $(20 \% \mathrm{Cu})>\mathrm{Cu}-\mathrm{TiO}_{2}(5 \% \mathrm{Cu})>$ rutile. The amount of $\mathrm{CH}_{4}$ produced in the presence of the catalyst containing $10 \mathrm{wt} \%$ of $\mathrm{Cu}$ was higher for ca. $7 \%$ than in case of crude anatasephase $\mathrm{TiO}_{2}$ and for ca. $33 \%$ than in case of pure rutile. The concentration of ethane was 14-16 times lower than the amount of methane. The lowest concentration of $\mathrm{C}_{2} \mathrm{H}_{6}$ after 5 hours of irradiation was observed for rutile ( $0.043 \mathrm{vol} . \%)$ and the highest for $\mathrm{CuO} /$ rutile catalyst containing $10 \mathrm{wt} \%$ of $\mathrm{Cu}(0.062 \mathrm{vol} . \%)$. The mechanism of methane generation from acetic acid followed the photo-Kolbe reaction pathway, what was concluded on a basis of $\mathrm{CH}_{4} / \mathrm{CO}_{2}$ ratio, which was found to be $\sim 1$. Low concentrations of hydrogen were also detected in the gaseous mixtures. The amount of $\mathrm{H}_{2}$ was increasing with increasing $\mathrm{Cu}$ loading. After 5 hours of irradiation about $0.06-0.14$ vol.\% of $\mathrm{H}_{2}$ was obtained for photocatalysts containing $5-20 \mathrm{wt} \%$ of $\mathrm{Cu}$, respectively. On the basis of the experimental data it is supposed that the source of hydrogen was acetic acid, not water.

Further investigations on the effectiveness of methane generation in the presence of $\mathrm{CuO} / \mathrm{TiO}_{2}$ photocatalyst are in progress.

\section{Acknowledgments}

This work has been supported by the Polish Ministry of Science and Higher Education as a scientific project no. N523 413435 (2008-2011). The author wish to thank Professor A. W. Morawski, Head of the Institute of Chemical and Environment Engineering for precious advices and creative discussion during preparation of this article. 


\section{References}

[1] G. Lastella, C. Testa, G. Cornacchia, M. Notornicola, F. Voltasio, and V. K. Sharma, "Anaerobic digestion of semi-solid organic waste: biogas production and its purification," Energy Conversion and Management, vol. 43, no. 1, pp. 63-75, 2002.

[2] V. Augugliaro, M. Litter, L. Palmisano, and J. Soria, "The combination of heterogeneous photocatalysis with chemical and physical operations: a tool for improving the photoprocess performance scale for the treatment of biorecalcitrant pollutants," Journal of Photochemistry and Photobiology C, vol. 7, no. 4, pp. 127-144, 2006.

[3] Slamet, H. W. Nasution, E. Purnama, S. Kosela, and J. Gunlazuardi, "Photocatalytic reduction of $\mathrm{CO}_{2}$ on copperdoped Titania catalysts prepared by improved-impregnation method," Catalysis Communications, vol. 6, no. 5, pp. 313-319, 2005.

[4] K. Kočí, L. Obalová, and Z. Lacný, "Photocatalytic reduction of $\mathrm{CO}_{2}$ over $\mathrm{TiO}_{2}$ based catalysts," Chemical Papers, vol. 62, no. 1, pp. 1-9, 2008.

[5] S. S. Tan, L. Zou, and E. Hu, "Photosynthesis of hydrogen and methane as key components for clean energy system," Science and Technology of Advanced Materials, vol. 8, no. 1-2, pp. 8992, 2007.

[6] C.-C. Lo, C.-H. Hung, C.-S. Yuan, and J.-F. Wu, "Photoreduction of carbon dioxide with $\mathrm{H}_{2}$ and $\mathrm{H}_{2} \mathrm{O}$ over $\mathrm{TiO}_{2}$ and $\mathrm{ZrO}_{2}$ in a circulated photocatalytic reactor," Solar Energy Materials and Solar Cells, vol. 91, no. 19, pp. 1765-1774, 2007.

[7] Y. Shiraishi and T. Hirai, "Selective organic transformations on titanium oxide-based photocatalysts," Journal of Photochemistry and Photobiology C, vol. 9, no. 4, pp. 157-170, 2008.

[8] I.-H. Tseng, J. C. S. Wu, and H.-Y. Chou, "Effects of solgel procedures on the photocatalysis of $\mathrm{Cu} / \mathrm{TiO}_{2}$ in $\mathrm{CO}_{2}$ photoreduction," Journal of Catalysis, vol. 221, no. 2, pp. 432 440, 2004.

[9] I.-H. Tseng, W.-C. Chang, and J. C. S. Wu, "Photoreduction of $\mathrm{CO}_{2}$ using sol-gel derived titania and titania-supported copper catalysts," Applied Catalysis B, vol. 37, no. 1, pp. 37-48, 2002.

[10] G. Guan, T. Kida, and A. Yoshida, "Reduction of carbon dioxide with water under concentrated sunlight using photocatalyst combined with Fe-based catalyst," Applied Catalysis B, vol. 41, no. 4, pp. 387-396, 2003.

[11] N. Sasirekha, S. J. S. Basha, and K. Shanthi, "Photocatalytic performance of $\mathrm{Ru}$ doped anatase mounted on silica for reduction of carbon dioxide," Applied Catalysis B, vol. 62, no. 1-2, pp. 169-180, 2006.

[12] S. S. Tan, L. Zou, and E. Hu, "Photocatalytic reduction of carbon dioxide into gaseous hydrocarbon using $\mathrm{TiO}_{2}$ pellets," Catalysis Today, vol. 115, no. 1-4, pp. 269-273, 2006.

[13] H. Yamashita, Y. Fujii, Y. Ichihashi, et al., "Selective formation of $\mathrm{CH}_{3} \mathrm{OH}$ in the photocatalytic reduction of $\mathrm{CO}_{2}$ with $\mathrm{H}_{2} \mathrm{O}$ on titanium oxides highly dispersed within zeolites and mesoporous molecular sieves," Catalysis Today, vol. 45, no. 14, pp. 221-227, 1998.

[14] O. Ozcan, F. Yukruk, E. U. Akkaya, and D. Uner, "Dye sensitized artificial photosynthesis in the gas phase over thin and thick $\mathrm{TiO}_{2}$ films under UV and visible light irradiation," Applied Catalysis B, vol. 71, no. 3-4, pp. 291-297, 2007.

[15] B. Kraeutler and A. J. Bard, "Photoelectrosynthesis of ethane from acetate ion at an $n$-type $\mathrm{TiO}_{2}$ electrode. The photo-Kolbe reaction," Journal of the American Chemical Society, vol. 99, no. 23, pp. 7729-7731, 1977.
[16] B. Kraeutler and A. J. Bard, "Heterogenous photocatalytic synthesis of methane from acetic acid-new Kolbe reaction pathway," Journal of the American Chemical Society, vol. 100, no. 7, pp. 2239-2240, 1978.

[17] B. Kraeutler, C. D. Jaeger, and A. J. Bard, "Direct observation of radical intermediates in the photo-Kolbe reactionheterogenous photocatalytic radical formation by electron spin resonance," Journal of the American Chemical Society, vol. 100, no. 15, pp. 4903-4905, 1978.

[18] T. Sakata, T. Kawai, and K. Hashimoto, "Heterogeneous photocatalytic reactions of organic acids and water. New reaction paths besides the photo-Kolbe reaction," Journal of Physical Chemistry, vol. 88, no. 11, pp. 2344-2350, 1984.

[19] G. R. Dey and K. K. Pushpa, "Methane generated during photocatalytic redox reaction of alcohols on $\mathrm{TiO}_{2}$ suspension in aqueous solutions," Research on Chemical Intermediates, vol. 32, no. 8, pp. 725-736, 2006.

[20] J. Bandara, C. P. K. Udawatta, and C. S. K. Rajapakse, "Highly stable $\mathrm{CuO}$ incorporated $\mathrm{TiO}_{2}$ catalyst for photocatalytic hydrogen production from $\mathrm{H}_{2} \mathrm{O}$," Photochemical and Photobiological Sciences, vol. 4, no. 11, pp. 857-861, 2005.

[21] Z. Jin, X. Zhang, Y. Li, S. Li, and G. Lu, " $5.1 \%$ apparent quantum efficiency for stable hydrogen generation over eosinsensitized $\mathrm{CuO} / \mathrm{TiO}_{2}$ photocatalyst under visible light irradiation," Catalysis Communications, vol. 8, no. 8, pp. 1267-1273, 2007.

[22] H.-J. Choi and M. Kang, "Hydrogen production from methanol/water photodecomposition over the $\mathrm{Cu}$ loaded $\mathrm{TiO}_{2}$," Applied Chemistry, vol. 10, no. 2, pp. 453-456, 2006.

[23] T. Sreethawong and S. Yoshikawa, "Comparative investigation on photocatalytic hydrogen evolution over $\mathrm{Cu}$-, $\mathrm{Pd}-$, and $\mathrm{Au}-$ loaded mesoporous $\mathrm{TiO}_{2}$ photocatalysts," Catalysis Communications, vol. 6, no. 10, pp. 661-668, 2005.

[24] S. Mozia, "Effect of calcination temperature on photocatalytic activity of $\mathrm{TiO}_{2}$. Photodecomposition of mono- and polyazo dyes in water," Polish Journal of Chemical Technology, vol. 10, no. 3, pp. 42-49, 2008.

[25] M. S. P. Francisco and V. R. Mastelaro, "Inhibition of the anatase-rutile phase transformation with addition of $\mathrm{CeO}_{2}$ to $\mathrm{CuO}-\mathrm{TiO}_{2}$ system: Raman spectroscopy, X-ray diffraction, and textural studies," Chemistry of Materials, vol. 14, no. 6, pp. 2514-2518, 2002.

[26] N. Todorova, T. Giannakopoulou, G. Romanos, T. Vaimakis, J. $\mathrm{Yu}$, and C. Trapalis, "Preparation of fluorine-doped $\mathrm{TiO}_{2}$ photocatalysts with controlled crystalline structure," International Journal of Photoenergy, vol. 2008, Article ID 534038, 9 pages, 2008.

[27] M. Subrahmanyam, S. Kaneco, and N. Alonso-Vante, "A screening for the photo reduction of carbon dioxide supported on metal oxide catalysts for $\mathrm{C}_{1}-\mathrm{C}_{3}$ selectivity," Applied Catalysis $B$, vol. 23, no. 2-3, pp. 169-174, 1999.

[28] M.-K. Jeon, J.-W. Park, and M. Kang, "Hydrogen production from methanol/water decomposition in a liquid photosystem using the anatase and rutile forms of $\mathrm{Cu}-\mathrm{TiO}_{2}$," Journal of Industrial and Engineering Chemistry, vol. 13, no. 1, pp. 84-91, 2007.

[29] T. Kawai and T. Sakata, "Photocatalytic hydrogen production from liquid methanol and water," Journal of the Chemical Society, Chemical Communications, no. 15, pp. 694-695, 1980.

[30] B. Zielińska, J. Sreńscek-Nazzal, and R. J. Kaleńczuk, "Photocatalytic hydrogen generation over alkali niobates in the presence of organic compounds," Polish Journal of Chemical Technology, vol. 10, no. 4, pp. 1-3, 2008. 
[31] B. Zieliñska, E. Borowiak-Paleń, and R. J. Kaleńczuk, "Photocatalytic hydrogen generation over alkaline-earth titanates in the presence of electron donors," International Journal of Hydrogen Energy, vol. 33, no. 7, pp. 1797-1802, 2008.

[32] K. G. Kanade, B. B. Kale, J.-O. Baeg, et al., "Self-assembled aligned Cudoped $\mathrm{ZnO}$ nanoparticles for photocatalytic hydrogen production under visible light irradiation," Materials Chemistry and Physics, vol. 102, no. 1, pp. 98-104, 2007.

[33] J. S. Jang, H. G. Kim, P. H. Borse, and J. S. Lee, "Simultaneous hydrogen production and decomposition of $\mathrm{H}_{2} \mathrm{~S}$ dissolved in alkaline water over $\mathrm{CdS}$. $\mathrm{TiO}_{2}$ composite photocatalysts under visible light irradiation," International Journal of Hydrogen Energy, vol. 32, no. 18, pp. 4786-4791, 2007.

[34] A. Kudo and Y. Miseki, "Heterogeneous photocatalyst materials for water splitting," Chemical Society Reviews, vol. 38, no. 1, pp. 253-278, 2009.

[35] M. Anpo, H. Yamashita, Y. Ichihashi, and S. Ehara, "Photocatalytic reduction of $\mathrm{CO}_{2}$ with $\mathrm{H}_{2} \mathrm{O}$ on various titanium oxide catalysts," Journal of Electroanalytical Chemistry, vol. 396, no. 1-2, pp. 21-26, 1995. 


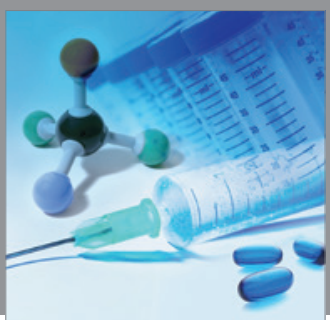

International Journal of

Medicinal Chemistry

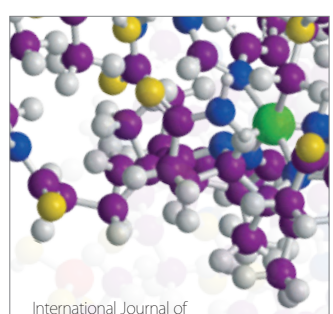

Carbohydrate Chemistry

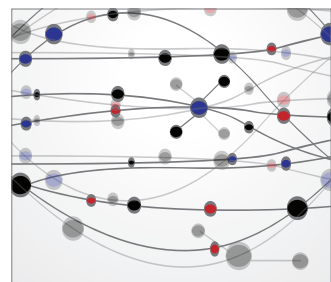

The Scientific World Journal
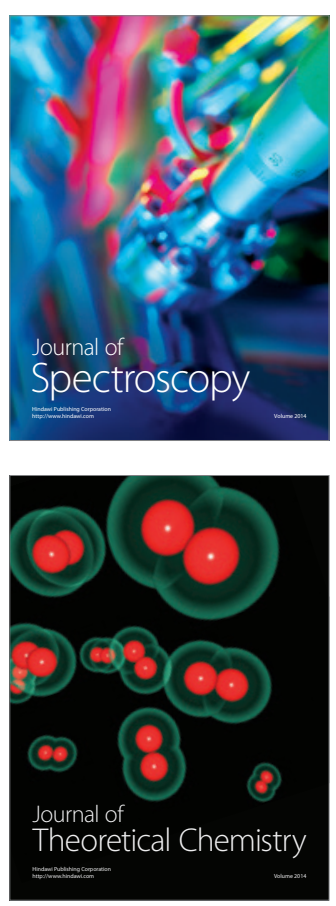
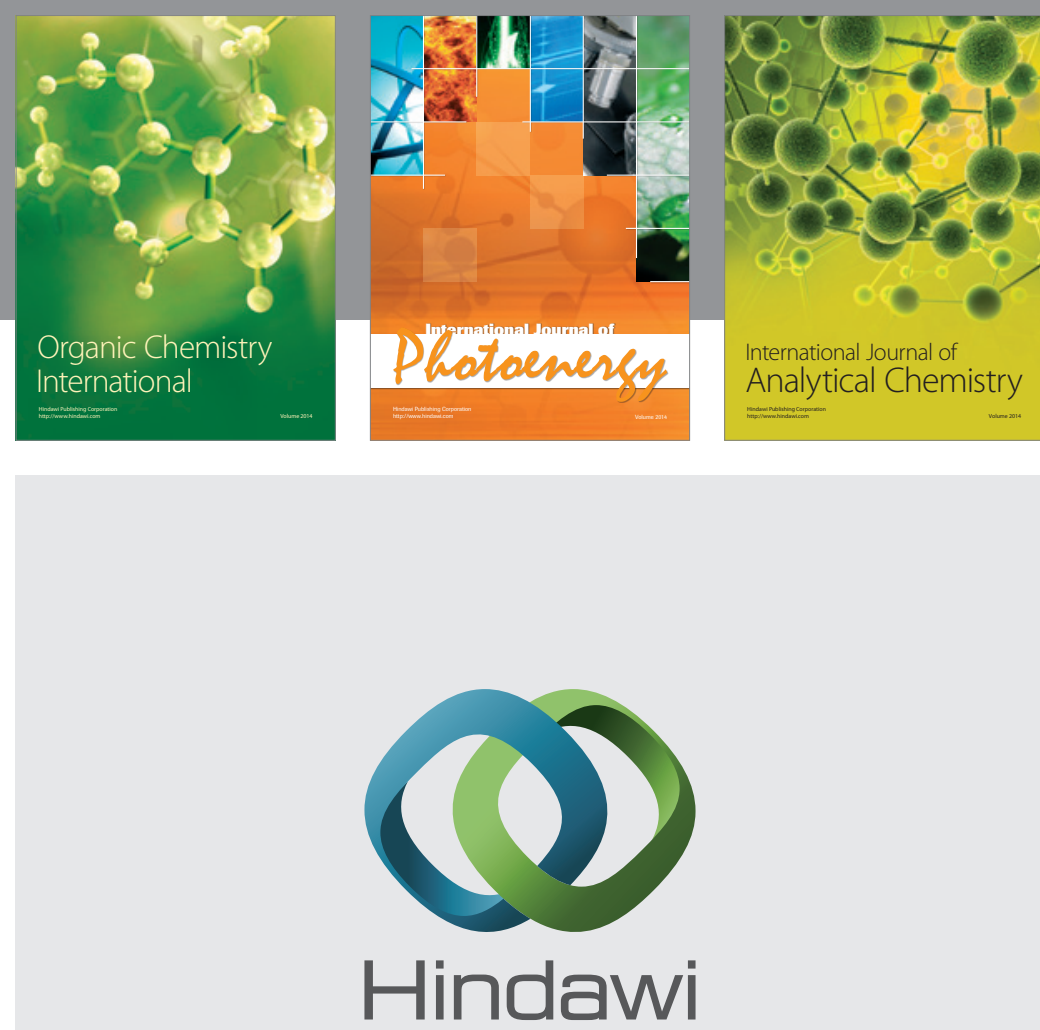

Submit your manuscripts at

http://www.hindawi.com
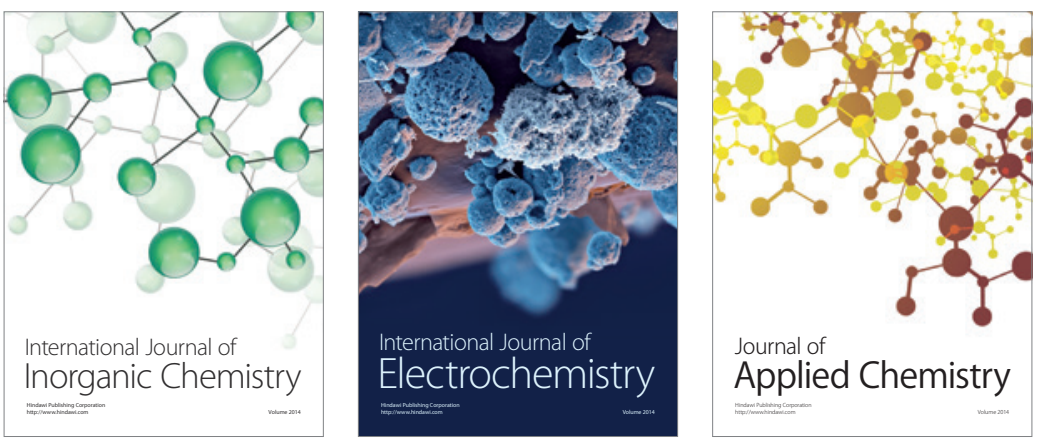

Journal of

Applied Chemistry
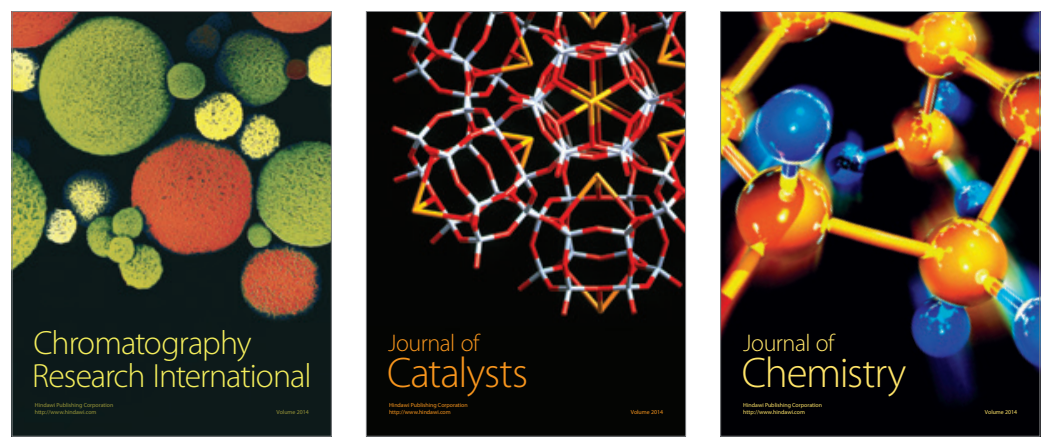
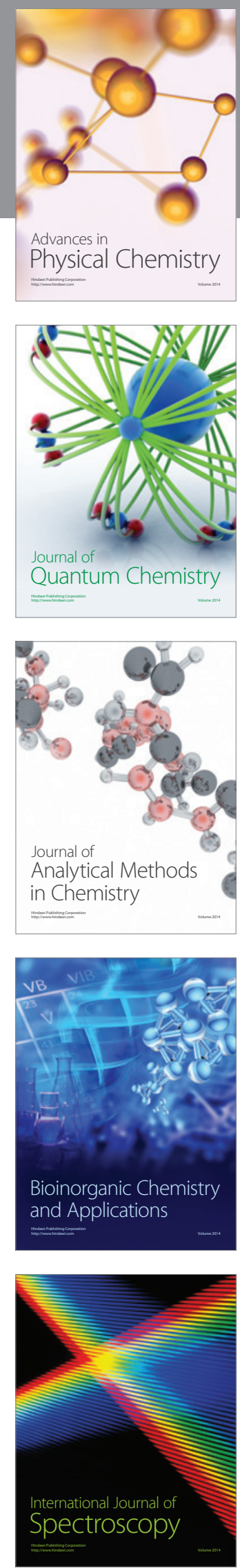